\title{
Substance Abuse In The Workplace
}

Carolyn Ashe, (Email: ashec@uhd.edu), University of Houston, Downtown

Chynette Nealy, (Email: nealyc@uhd.edu), University of Houston, Downtown

\begin{abstract}
Substance abuse is a problem that many businesses encounter. Seventy-one percent of illegal drug users were employed in 1991 compared to 76.4 percent in 2001(National Alcohol and Drug Addiction Recovery month, 1999; National Household Survey on Drug Abuse, 2001). This paper presents findings from a study conducted to determine (1) if employers and employees agree about the importance of a substance abuse program in the workplace, (2) the extent the employer should be allowed to probe to identify employee substance issues, and (3) factors associated with an employee's reluctance to seek help from their employer for drug or alcohol abuse.
\end{abstract}

\section{INTRODUCTION}

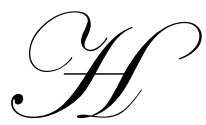

ow important is the implementation of a substance abuse policy and a substance-testing program in the workplace? Such a policy and testing program can reduce the number of substance related accidents (Dimoff, 2001). Addiction is an uncontrollable compulsion to repeat a behavior regardless of its negative consequences (Bambooweb Dictionary, 2005).

As much as $40 \%$ of industrial fatalities and approximately $47 \%$ of industrial injuries can be associated with alcohol consumption and alcoholism. Drug addiction, marijuana and cocaine, increases these percentages in corporate America. Interestingly enough, 75\% of cocaine users reported using cocaine on the job (Dimoff, 2001; Drug Abuse: It Affects Us All, 2005; What Every Employer Should Know About Drug-Abuse in the Workplace, 2004; Workplace Substance Abuse, 2004).

Substance abuse is defined as the overindulgence in and dependence on an addictive substance, especially alcohol or a narcotic drug (The American Heritage dictionary, 2000). The substance abuser cannot be defined by (1) gender, (2) financial or (3) professional groups. Thus, any employee has the possibility of being a substance abuser. When supervised closely, absenteeism also becomes a factor. By forming a closely-knit network, this will allow employees to cover up for each other. In this situation, a substance dealing problem exists as well (Dimoff, 2001; Employment and Training Administration, 2005).

An Employee Assistance Program (EAP) has been implemented in countless companies to assist employees in achieving and maintaining sobriety. According to Dimoff (2001), organizations should adhere to the following when dealing with drugs in the workplace:

- Create a policy on drugs;

- Conduct a pre-employment screening;

- Implement a pre-employment drug-screening program;

- Implement an Employee Assistance Program (EAP);

- Communicate policy effectively to all employees;

- Train managers to recognize signs of substance abuse;

- $\quad$ Establish an anonymous information tip line;

- $\quad$ Provide managers with an action plan once a suspected employee is reported;

- Thorough investigation and documentation of reported drug usage; and

- Notify the employee and follow-up with appropriate action as outlined in the policy. 


\section{PURPOSE}

The purpose of this study was to determine (1) if employers and employees agree about the importance of a substance abuse program in the workplace, (2) the extent the employer should be allowed to probe to identify employee substance issues, and (3) factors associated with an employee's reluctance to seek help from their employer for drug or alcohol abuse. Thus, the research questions were as follows:

- Do employers and employees agree about the importance of a substance abuse program in the workplace?

- $\quad$ Should employers be allowed to probe to identify employee issues?

- What factors are associated with employee's reluctance to seek help from employers for drug or alcohol abuse?

\section{METHODOLOGY}

\section{Participants And Procedures}

A survey was given to 58 employees at five different companies. All of the surveys were complete and included in the analysis. The five companies were from the following kinds of businesses and industries: financial, manufacturing, oil and gas or medical. The instrument was developed from knowledge obtained from secondary research of the topic.

Three separate interviews were conducted with management in the Human Resources Department of organizations in a large metropolitan area. The medical, oil and gas, financial and manufacturing industries were represented. Each interview was conducted in the same manner by asking the same questions pertaining to the topic of alcohol and substance abuse. Confidentiality was maintained for participants.

\section{Instrument}

The primary means for collecting data were the survey and interviews. Demographic information was collected from each participant. Data included age, gender, and education. Delimitations

Despite the precautions taken, the following opportunities for error or skew factors may still exist:

- $\quad$ personal biases

- $\quad$ apathetic attitudes

- $\quad$ confusing or misleading survey format

- $\quad$ persistence of distrust or discomfort regarding the research

The survey and interview results are found in the sections that follow.

\section{FINDINGS}

\section{Survey} (see Table 1).

Basic statistical calculations were used to simplify the results of the 58 surveys collected from employees 
Table 1

\begin{tabular}{|l|c|c|}
\hline Should the employer: & $\#$ & Yes (\%) No(\%) \\
\hline Have a drug abuse policy? & 58 & 84.2 \\
\hline Administer drug tests? & 58 & 89.5 \\
\hline Provide employee assistance? & 58 & 47.8 \\
\hline Give a second chance? & 58 & 52.6 \\
\hline
\end{tabular}

The first research question was answered affirmatively by the majority $(84.2 \%)$ of the respondents. The employees as well as the employer saw the importance of a drug abuse policy and believed a drug abuse policy should exist. Almost $90 \%$ of the employees agreed that the employer should administer drug tests and $86.8 \%$ of the employees felt the employer should give employees a second chance if abuse is found. But the majority (52.6\%) of responding employees believed the employer should not provide employer assistance. This response was surprising and the researchers believe this should be further investigated to determine the reasoning behind the response.

The research question, what factors are associated with an employee's reluctance to seek help from employers for drug or alcohol abuse revealed four significant factors (Table 2):

- Fear of termination

- Denial about the problem

- Concern about reputation/embarrassment

- Financial consequences

Table 2

\begin{tabular}{|l|c|c|}
\hline Factors & $\#$ & Mean* Mode** \\
\hline Fear of Termination & 58 & 8.89 \\
\hline Denial About Problem & 58 & 7.62 \\
\hline Concern About Reputation / Embarrassment & 58 & 7.49 \\
\hline Financial Consequences & 58 & 6.43 \\
\hline
\end{tabular}

* Mean is the sum of the ratings given to a particular question divided by the number of participants.

** Mode of each data set is the value in a set that occurs most frequently.

All of the mean and mode values presented are based on a scale from 1 (least important) to 10 (most important). Financial Consequences was of least importance to the responding employees when identifying factors that are associated with an employee seeking help from employers for drug or alcohol abuse. Whereas, fear of termination and denial about the problem rated most important; concern about reputation/embarrassment rated third in consideration.

Several of the survey participants shared the following experiences concerning company substance abuse policies in the Comment section of the survey:

- "[Payment and fee terms for employer assistance] should be included with insurance package. Also, if employer suspects [drug or alcohol] abuse, the company should pay for testing. Substance abuse policy should only be directed at problems that conflict with employee's ability to perform his/her job. Problems that arise on personal time are responsibility of individual."

- $\quad$ "I strongly believe that alcohol and substance abuse is an illness and that not only family and friends should take part in their help and support, but that your employer should also take part in some type of alcohol and substance [abuse] policy as well!"”

- $\quad$ "On testing - would support if [it was] confidential and done off-site by lab and only if [there was] suspected abuse."

- "Most of the people I know that have an abuse problem don't think they have a problem."

- $\quad$ "... One day the manager of the store [I was working at] announced that we would be required to take a 
urine test........ when he announced it and then went to his office for some paperwork, several of the employees walked out of the store."

\section{Interviews}

Each interview was conducted in the same manner by asking the same questions pertaining to the topic of substance abuse. The questions and managers' responses are below.

- $\quad$ Is your company a drug free environment? The managers agreed they are required to notify all employees they are a drug-free workplace and the unlawful manufacture, sale, distribution, dispensing, possession or use of a controlled substance in or on any premises or property owned or controlled by the company is prohibited.

- When asked about random drug testing, the (oil and gas or medical institution) did not provide them while the two financial institutions did.

- If substance abuse is suspected, the companies provided an Employee Assistance Program (EAP) for the employee. This program is strictly voluntary and provides confidential initial counseling and referral. An employee can be either referred to EAP or the employee can refer him or herself. There is no charge for services rendered by EAP, although the employee's insurance is considered for future referrals. Other costs are the responsibility of the employee and cannot be funded or subsidized by the EAP (Texas A\&M University at Galveston, 2005).

- $\quad$ Most companies provide an alcohol and drug abuse policy that is given to all new employees when hired. The policy gives very detailed information to employees and substance abuse on the job.

- $\quad$ Any use or distribution of drugs while on the premises is prohibited. The medical institution will not allow their employee's to consume alcohol or uncontrolled substances while at a company function. It is felt that this may affect the health and/or safety of employees as well as others. Employees in violation of this policy are subject to disciplinary action up to and including termination. The policy has several suggestions that employees are required to follow when dealing with alcohol and uncontrolled substances. An example of this would be that if an employee is taking prescription drugs, he/she must notify the supervisor in writing of the possible side effects.

- If an employee is suspected of substance abuse and this is clearly seen by their work performance, then the employee or their supervisor is referred to the Employee Assistance Program (EAP) for counseling. EAP is designed to provide assistance for employees at correctional managed care and other offsite locations.

- $\quad$ Once an employee has completed treatment and/or counseling, they will be eligible for active employment status without reduction in pay or seniority. The job placement might be different; however, they will not lose pay or benefits. Most companies require that when an employee returns to work, they bring a lab result stating $t$ they are drug free.

The overall purpose of the policy is to identify and remove the adverse effects of alcohol and drugs from the workplace, and to protect the health and safety of employees by providing education and treatment.

\section{CONCLUSIONS}

Substance abuse is a problem that many businesses encounter. Seventy-one percent of illegal drug users were employed in 1999 as compared with 76.4 percent of employees in 2001 (National Alcohol and Drug Addiction Recovery Month, 1999; National Household Survey on Drug Abuse, 2001). In order to maintain a productive and safe workplace, the employer has the responsibility to intervene when there is a problem in the workplace (United States Department of Labor Office on the Solicitor, 1998). The first step a company must take is to implement a substance abuse policy. When writing a substance abuse policy the moral philosophy of teleology which also includes egoism and utilitarianism could be a good basis to start. This policy should clearly state what the company's position is towards substance abuse. The policy should also be straight-forward and use simple wording. The policy should also contain the reasons why the policy is being implemented. The most important reasons that could be included are the safety of the employees and customers as well as to improve productivity and control the costs of doing business. The policy should also include what exactly it prohibits as well as what the consequences would be (Taking a Stand 
Against Substance Abuse With a Written Policy Statement, 1998).

One way to minimize employees with a substance abuse problem is to establish substance abuse testing. A test that can be administered is the pre-employment test. By making this test a requirement for employment it will eliminate any people that have a substance abuse problem. Therefore, in order to maintain a drug or alcohol free environment an employer can select to perform random drug testing on employees. There does not have to be suspicion of substance abuse in order to submit an employee to random testing as long as it is part of the written policy. In the case that an employer has reasonable suspicion that an employee has a substance abuse problem they can request that the employee be tested. Of course, an employer should always be certain and have evidence that justifies an employee being tested.

Another way an employee can be tested is by the post accident test. The employer requires this test when a serious accident on the job has occurred. In order for an employer to implement substance abuse testing they must first have a written policy in the employee's handbook. The employee must be aware of this policy; therefore, the employer must have the employee sign acknowledgment of the policy. There must also be trained staff knowledgeable about how to proceed when an employee must be submitted to testing (Bendavid-Arbiv, 2001).

In the case that there is a substance abuse issue the employer must know how to intervene. The employer must always maintain control of the conversation when notifying the employee. Specific situations on how the employee's work performance has declined and supporting documents or records of specific events that have occurred must always be used. In order to be clear and firm with the employee, the company's policy should be brought to the employee's attention. Explain the policies concerning performance, substance abuse and the consequences if the policies are not abided. An employer must not get emotionally involved but they should be supportive by offering to help the employee by suggesting possible solutions (Substance Abuse: Symptoms and Intervention, 1998).

Employers should be aware of any consequences that might arise due to implementing a substance abuse policy and testing for either alcohol or drugs. If the employer does not take the proper steps conducting a test or notifying an employee who is suspected to have a substance abuse problem, the employee can file a lawsuit against the company. For instance an employer has to take in consideration that an employee's behavior or performance does not always indicate that he or she has a substance abuse problem. Other reasons for employee changes in behavior or performance could be lack of sleep, personal problems, or medications an employee might be taking. In order to avoid any legal problems a reasonable suspicion test should only be conducted if the employer has enough evidence to justify the test (Avitar on Site Diagnostics, 2005).

An analysis of data revealed that while the financial business did administer random testing, the oil and gas or medical business did not. A survey was completed by 58 participants.

Surveys reveled that $84.2 \%$ of the employees believe that there should be a substance abuse policy in the workplace and about $89.5 \%$ believe that drug test should be administered to employees. The researchers concluded based on an analysis of data that in order for a business to provide a safe and productive work environment the organization has to implement a substance abuse policy and testing for employees.

\section{REFERENCES}

1. American Heritage Dictionary (2000), $4^{\text {th }}$ edition, Houghton-Mifflin Publishing. Retrieved June 10, 2005 from http://education.yahoo.com/reference/dictionary/entry?id=s0852550

2. Avitar on Site Diagnostics, Employee Drug Testing in the Workplace is Our Core Business (2005). Retrieved March 10, 2005 from <http://www.avitarinc.com/Drug_Testing/employee-drug-testing.cfm>

3. BambooWeb Dictionary (2005). Retrieved June 27, 2005 from http://www.bambooweb.com/ articles/a/d/Addictive.html

4. Bendavid-Arbiv, Sue. Employment Law: Employers must enforce drug-testing policies in a way that minimizes exposure to tort claims. Find Law Dec. 2001. Retrieved March 10, 2005 from

<http://library.findlaw.com/2001/Dec/19/130860.html> 
5. Dimoff, Timothy A. (2001). How to Recognize Substance Abuse (Chapter 10). Retrieved June 14, 2005 from http://www.sacsconsulting.com/book/chapter10.htm

6. Drug Abuse: It Affect Us All (2005). Abbott Laboratories, Diagnostics. Retrieved June 5, 2005 from http://www.abbottdiagnostics.com/Your_Health/Drug_Abuse/

7. Employment \& Training Administration (2005). U.S Department of Labor. <http://www.doleta.gov>

8. $\quad$ Human Resources Director. Personal Interview. 28 Mar. 2005.

9. National Alcohol and Drug Addiction Recovery Month 1999, "Reassembling Human Assets Through Substance Abuse Awareness.” Retrieved March 10, 2005 from http://www.recoverymonth.gov/ 1999/exemplar/manuf.htm

10. National Household Survey on Drug Abuse, 2000. Illicit Drug Use. Retrieved August 2, 2005 from http://www.oas.samhsa.gov/nhsda/2k1nhsda/vol1/chapter2.htm\#2.empl

11. Substance Abuse: Symptoms and Intervention. Find Law Nov. 1998. Retrieved March 20, 2005 from <http://library.findlaw.com/1998/Nov/6/128147.html>

12. Taking a Stand Against Substance Abuse With a Written Policy Statement U. S. Department of Labor, Nov. 1998. Retrieved on March 10, 2005 from <http://library.findlaw.com/1998/Nov/6/129731.html>

13. Texas Commission of Alcohol and Drug Abuse. Alcohol/Drug Use/Abuse Policy. Texas: 2003.

14. Texas A\&M University at Galveston, Employee Assistance Program. Retrieved March 20, 2005 from http://www.tamug.edu/hrd/eap.html.

15. United States Department of Labor Office on the Solicitor. Affecting Your Company's Bottom Line Through Substance Abuse Awareness Find Law Nov. 1998. Retrieved March 20, 2005 from <http://library.findlaw.com/1998/Nov/6/130028.html>

16. University of Texas Medical Branch. Alcohol and Drug-Free Workplace, MCHR-3.1.B. April 1997.

17. What American Employees Think About Drug Abuse (1997). Retrieved on May 26, 2005 from http://www.drugfreeworkplace.org/survey/.

18. What Every Employer Should Know About Drug-Abuse in the Workplace (2004). OHS Health and Safety Services, Inc., Parts 1 and 2. Retrieved on June 5, 2005 from http://www.ohsinc.com/ what_every_parent_should_know_part1.htm

19. Workplace Substance Abuse: Symptoms and Intervention, December 2004. Retrieved May 26, 2005 from $<$ http://www.jedlet.com> 